\title{
Evaluation of drought tolerance of triticale (xTriticosecale Wittm. ex A. Camus) genotypes along with bread wheat and barley genotypes
}

\author{
Seyyed Hamid Reza RAMAZANI ${ }^{1,2}$, Ali IZANLOO ${ }^{1}$
}

Evaluation of drought tolerance of triticale (xTriticosecale Wittm. ex A. Camus) genotypes along with bread wheat and barley genotypes

Abstract: The effects of drought stress on morphological and yield traits of six different genotypes of triticale along with wheat and barley were studied. The experiment was conducted in agricultural college of Sarayan, University of Birjand in 20162017 growing season. Experiment was a split-plot experiment based on randomized complete block design with drought stress in main plots and eight mentioned genotypes in subplots in three replications. Results of analysis of variance and means comparison analysis showed significant and negative effect of drought stress on grain yield and biological yield of all investigated genotypes. There was significant difference among investigated genotypes of triticale, wheat, and barley for grain yield under drought stress at $1 \%$ probability level. Pazh genotype of triticale was found as the most drought tolerance genotype, among all investigated genotypes, based on almost all drought tolerance indexes. The highest significant correlation with grain yield was related to biological yield, harvest index, spike/shoot ratio, height and straw yield. GGE biplot analysis of genotypes based on their Yp and Ys showed that Pazh, Jualino, and Sanabad genotypes of triticale had more trends to Ys principal component than ET-89-11 line, wheat, and barley genotypes, therefore show more tolerance to drought stress.

Key words: biplot; correlation; drought stress; tolerance index; Triticale
Received April 13, 2018; accepted June 17, 2019.

Delo je prispelo 13. aprila 2018, sprejeto 17. junija 2019.
Ovrednotenje odpornosti genotipov tritikale (xTriticosecale Wittm. ex A. Camus) na sušo v primerjavi z genotipi krušne pšenice in ječmena

Izvleček: V raziskavi so bili preučevani učinki sušnega stresa na morfološke lastnosti in lastnosti pridelka šestih različnih genotipov tritikale $\mathrm{v}$ primerjavi $\mathrm{s}$ pšenico in ječmenom. Poskus je bil izveden na Agricultural College of Sarayan, University of Birjand, v rastni sezoni 2016-2017. Poskus je bil popolni naključni bločni poskus z deljenkami, s sušnim stresom na glavnih ploskvah in osmimi genotipi žit na podploskvah s tremi ponovitvami. Rezulati analize variance in analize primerjave poprečij so pokazali značilne negativne učinke sušnega stresa na pridelek zrnja in biološki pridelek pri vseh preučevanih genotipih. Med preučevanimi genotipi tritikale, pšenice in ječmena je bila značilna razlika $\mathrm{v}$ pridelku zrnja v razmerah sušnega stresa pri $1 \%$ verjetnosti. Med vsemi preučevanimi genotipi se je na osnovi skoraj vseh indeksov tolerance na sušo sorta tritikale 'Pazh' izkaza kot najbolj na sušo odporen genotip. Največja značilna korelacija s pridelkom zrnja je bila povezana $\mathrm{z}$ biološkim pridelkom, žetvenim indeksom, razmerjem klas/poganjek, višino rastlin in pridelkom slame. GGE biplot analiza genotipov, ki je temeljila na njihovih Yp in Ys je pokazala, da imajo genotipi triticale Pazh, Jualino, in Sanabad večjo povezavo z glavno komponento Ys kot ET-89-11 linija pšenice in genotipi ječmena, kar kaže njihovo večjo tolerance na sušni stress.

Ključne besede: biplot; korelacija; sušni stres; indeks tolerance; Triticale

1 University of Birjand, Department of Agronomy and Plant Breeding, Agricultural Collage of Sarayan

2 Corresponding author, e-mail: hrramazani@birjand.ac.ir 


\section{INTRODUCTION}

Growing world population lead to the expected global demand for cereals in the coming decades. Triticale (x Triticosecale Wittm. ex A. Camus) is a new successful cereal that derived from hybridization of wheat (Triticum spp.) and rye (Secale spp.) (Ramazani et al., 2016, 2017). Indeed, triticale is referring to fusion of the Latin words of Triticum (wheat) and Secale (rye). The first attempts for artificial crosses between wheat and rye were reported in 1875 (Oettler, 2005). Anyway, the first commercial winter triticale was released in Hungary in 1968 , and then, discovering of Armadillo by the International Maize and Wheat Improvement Center (CIMMYT) led to the release of numerous commercial triticale cultivars in future (Oettler, 2005). Breeding programs that conducted in several countries lead to rapid improvement of triticale. Because of its higher protein and lysine content, than wheat, triticale is often used as feed grain in mixed diets. Combination of the good grain quality and the high yield potential of wheat with the biotic and abiotic stress tolerance of rye leads to it that triticale be more suitable for marginal environments and soils (Bassu et al., 2011).

Prolonged water deficit is a major abiotic stress $(\mathrm{Fa}-$ rooq et al., 2009). One of the major constrain for productivity of cereal crops is drought stress, and under future climate change scenarios water deficit will increase in most arid and semi-arid regions (Wassmann et al., 2009). Breeding for a quantitative trait with low heritability such as drought resistance is so complicated and using of certain criterions that quantify the level of drought tolerance is more suitable than a direct selection criterion (Farshadfar \& Sutka, 2002). In this situation, plant breeders prefer to use of drought indices that provide a measure of drought stress based on yield loss under drought stress conditions in comparison to normal conditions (Mitra, 2001). A common starting point in the identification of traits related to drought tolerance is the relative yield performance of genotypes under drought-stressed and normal environments, which can use for the selection of genotypes in breeding for dry environments (Clarke et al., 1992). Several selection indices have been developed by various researchers based on a mathematical relationship between favorable and stress conditions (Clarke et al., 1984; Huang, 2000). Indices such as tolerance (TOL) (McCaig \& Clarke, 1982; Clarke et al., 1992), mean productivity (MP) (McCaig \& Clarke, 1982), stress susceptibility index (SSI) (Fischer \& Maurer, 1978), geometric mean productivity (GMP) (Fernandez, 1992), harmonic mean (HARM) (Schneider et al., 1997), relative drought index (RDI) (Fischer \& Wood, 1979), and stress tolerance index (STI) (Fernandez, 1992) have been used.

One of the wide-spread problems that seriously in- fluences cereal production and quality is drought stress (Kutlu \& Kinaci, 2010). Reproductive phase is the most susceptible stage to water deficit stress (Blum, 2011; Ramazani et al., 2019). The aims of the present study were to assess the effect of late drought stress on the agronomic characteristics of different genotypes of triticale along with two genotypes of bread wheat and barley and to find drought tolerance genotypes based on drought tolerance indicates.

\section{MATERIALS AND METHODS}

\subsection{PLANT MATERIALS}

Six new and superior genotypes of triticale including three cultivars (Jualino, Pazh, and Sanabad) and three elite line (ET-89-6, Et-89-9, and ET-89-11) along with one bread wheat cultivar (Pishgam) and one barley cultivar (Nik) were selected for evaluation. The experiment was conducted in the experimental field of Sarayan agricultural college, University of Birjand in South Khorasan province-Iran, in 2016-2017 growing season.

\subsection{EXPERIMENTAL CONDITIONS}

The experiment was carried out in the form of split-plot based on randomized complete block design (RCBD) with drought stress in main plots and eight aforementioned genotypes (six genotypes of triticale plus two genotypes of wheat and barley) in subplots in three replications. All investigated genotypes were cultivated in their allocated subplots. Each subplot contained 6 rows with $6 \mathrm{~m}$ length and with $20 \mathrm{~cm}$ distance between lines. In the normal experimental field, normal irrigation of cereal was applied but in drought stress environment, irrigation was interrupted in the flowering stage of genotypes.

Phonological assessments including number of days to flowering (DTF), and number of days to maturity (DTM) along with morphological characteristics of plant height $(\mathrm{PH})$ and chlorophyll content $(\mathrm{CC})$ were conducted during the growing season. The ratio of spike to shoot dry matter in main shoot for 10 plants was calculated in flowering $\left(\mathrm{SP} / \mathrm{S}_{\mathrm{F}}\right), 10$ days after flowering $\left(\mathrm{SP} / \mathrm{S}_{10 \mathrm{dff}}\right), 20$ days after flowering $\left(\mathrm{SP} / \mathrm{S}_{20 \mathrm{df}}\right)$, and in seed formation (SP/ $\mathrm{S}_{\mathrm{SF}}$ ) stages. At the end of growing season, number of tiller (NT), number of fertile tiller (NFT), stem diameter (SD), spike length (SL), root length (RL), number of spikes/ plant (NSP), number of spikes $/ \mathrm{m}^{2}$ (NS), number of seed/ spike (NS/S), number of seed/m² (NSM),1000-seed mass 
(TW), biological yield (BY), grain yield (GY), straw yield (SY), harvest index (HI), and water use efficiency for grain yield (WUE) were recorded separately. For this, the ratio of grain yield to actual evapo-transpiration was defined.

\subsection{DROUGHT TOLERANCE INDICES}

To calculate drought tolerance indicators, potential yield of each genotype in normal $\left(\mathrm{Y}_{\mathrm{p}}\right)$ and drought stress environment $\left(\mathrm{Y}_{\mathrm{s}}\right)$, average performance of all investigated genotypes in normal and drought stress environment were estimated and then TOL, MP, GMP, SSI, HARM, RDI, and STI were calculated according to below equations respectively:

\begin{tabular}{|c|c|}
\hline $\mathrm{Mp}=\frac{\mathrm{Yp}+\mathrm{Ys}}{2}$ & (1) (McCaig \& Clarke, 1982; Clarke et al., 1992 \\
\hline $\mathrm{SSI}=\frac{1-\left(\frac{Y_{s}}{Y_{p}}\right)}{1-\left(\frac{\gamma_{s}}{Y_{p}}\right)}$ & (2) (McCaig \& Clarke, 1982) \\
\hline $\mathrm{GMP}=\sqrt{\mathrm{Yp} \times \mathrm{Ys}_{\mathrm{S}}}$ & (3) (Fernandez, 1992) \\
\hline $\mathrm{TOL}=\frac{\mathrm{Yp}}{\left(\frac{Y \mathrm{~s}}{\mathrm{Yp}_{\mathrm{p}}}\right)}-\mathrm{Ys}$ & $\begin{array}{l}\text { (4) (Fischer \& Maurer, 1978) } \\
\text { (5) (Schneider et al., 1997) }\end{array}$ \\
\hline HARM $=\frac{2\left(\frac{Y_{s}}{P_{p}}\right)}{}$ & (6) (Fischer \& Wood, 1979) \\
\hline $\begin{array}{l}\text { STI }=\frac{Y_{s \times Y p}}{\bar{Y}_{p}^{2}}\end{array}$ & (7) (Fernandez, 1992) \\
\hline $\mathrm{YI}=\mathrm{YS} / \overline{\mathrm{YS}_{\mathrm{S}}}$ & (8) (Gavuzzi et al., 1997) \\
\hline $\mathrm{YSI}=\mathrm{Ys} / \overline{\mathrm{Yp}}$ & (9) (Bouslama \& Schapaugh, 1984) \\
\hline
\end{tabular}

\subsection{STATISTICAL ANALYSIS}

Statistical analyses including analysis of variance (ANOVA) and mean comparison analysis were carried out using SAS software (Ver. 9.2). Means comparison analysis was conducted using Duncan's multiple range test at $5 \%$ probability level. All drought tolerance indices were calculated using Excel 2010 software. Simple Pearson correlation analysis was carried out to calculate correlation of investigated plant characteristics and estimated drought tolerance indexes using SAS software. Biplot diagrams were drawn using Excel 2010 software.

\section{RESULTS AND DISCUSSION}

\subsection{ANALYSIS OF VARIANCE AND MEANS COM- PARISON}

The results of analysis of variance showed significant effect of drought stress on days to flowering, spike length, spike to shoot ratio at flowering and seed formation stage, and straw yield at $5 \%$ probability level and on plant height, root length, number of seeds/spike, number of seed $/ \mathrm{m}^{2}$, biological yield, grain yield, harvest index, and water use efficiency for grain yield in investigated genotypes of triticale, barley, and wheat at $1 \%$ probability level (Table 1). Based on the results of analysis of variance there were significant differences among investigated genotypes of triticale, barley and wheat for days to flowering, days to maturity, plant height, number of tiller, number of fertile tiller, spike length, spike to shoot ratio at 20 days after flowering and seed formation stages, straw yield, number of seeds per spike, grain yield, and harvest index at $1 \%$ probability level, and for spike to shoot ratio at flowering stage, number of seeds per $\mathrm{m}^{2}$, number of spikes per plant, and biological yield at $5 \%$ probability level (Table 1 ). Based on the results on analysis of variance, interaction effect of drought stress $\times$ genotype was only significant on number of tiller, straw yield, and number of spikes $/ \mathrm{m}^{2}$ traits at $5 \%$ probability level (Table 1). Means comparison analysis showed adverse effect of drought stress on plant height, spike to shoot ratio at 20 days after flowering and seed formation stages, straw yield, number of seed $/ \mathrm{m}^{2}, 1000$ seed mass, biological yield, grain yield, and water use efficiency (Table 1). Kutlu \& Kinaci (2010) also reported lower values for yield and yield components under rain fed conditions in comparison to irrigated conditions in three Turkish cultivars of triticale. Based on means comparison analysis drought stress lead to increase of root length of investigated genotypes and there was significant difference between root length of triticale, barley, and bread wheat genotypes under normal irrigation and drought stress condition at $5 \%$ probability level (Table 1). Means comparison analysis showed that the highest mean of number of days to flowering was related to Pishgam genotype of bread wheat whereas the lowest mean of this phonological trait was related to Jualino genotype of triticale (Table 1). For number of days to maturity all investigated genotypes of triticale had higher means than barley and wheat genotypes but there was no significant difference between them (Table 1). Early heading is a characteristic that can lead to a greater capacity for soil moisture extraction and greater drought resistance in triticale (Blum, 2014). The highest means of plant height were related to Jualino and Sanabad genotypes of triticale whereas the lowest mean of this trait was related to Pishgam genotype of bread wheat (Table 1). Results of Duncan's means comparison multiple range test analysis at $5 \%$ probability level showed that the highest mean of number of tiller was related to Nik genotype of barley and the lowest mean of this characteristic was achieved from ET-89-6 genotype of triticale (Table 1). Based on means compari- 


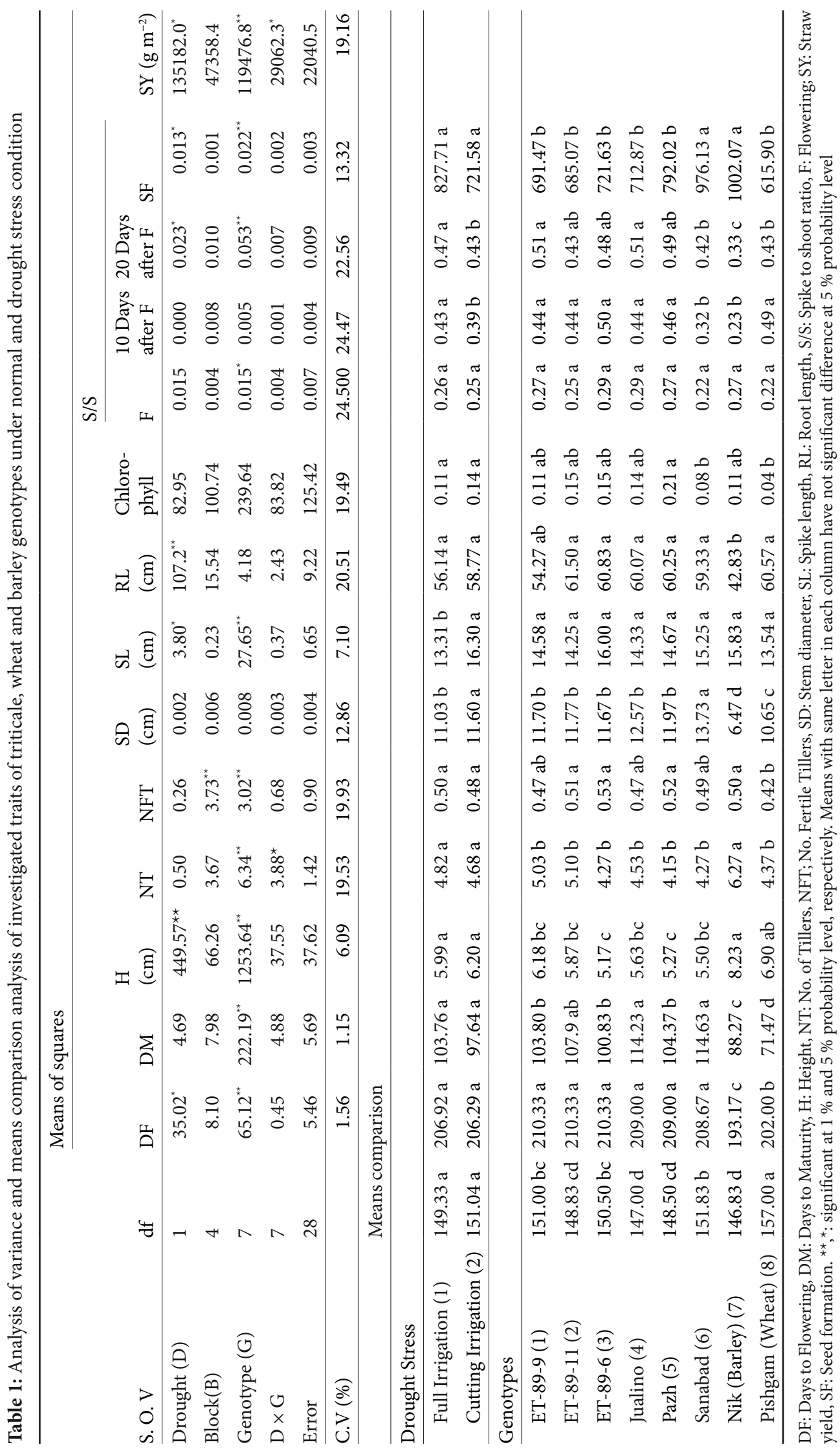




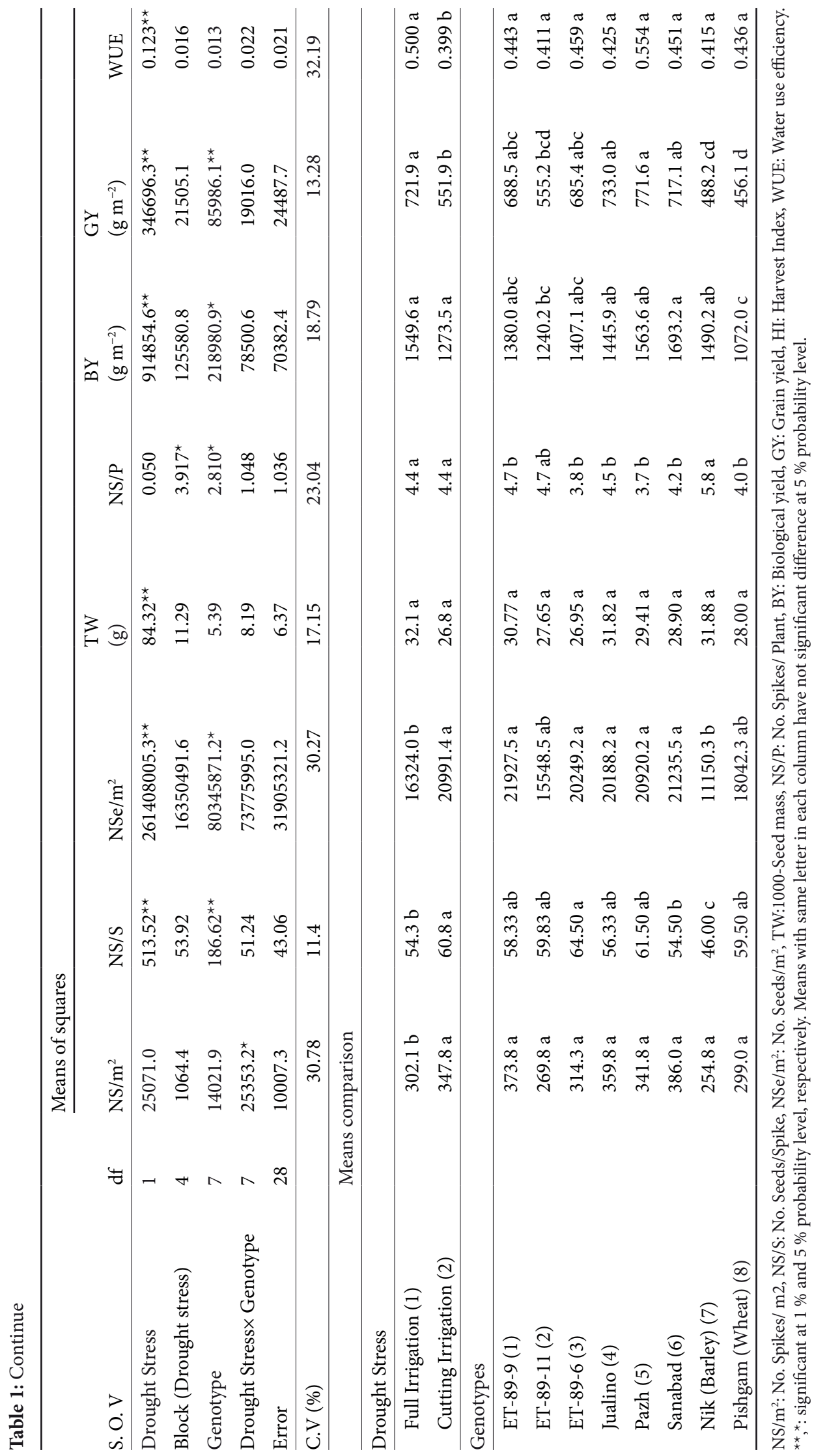


son analysis there was no significant difference between all investigated genotypes of triticale and Pishgam genotype of wheat for number of fertile tiller at $5 \%$ probability level but there was significant difference between these genotypes and Nik genotype of barley at $5 \%$ probability level (Table 1). Means comparison analysis showed that the highest and the lowest means of spike length were related to Sanabad genotype of triticale and Nik genotype of barley, respectively (Table 1). The highest mean of spike to shoot ratio at flowering stage was achieved from Pazh genotype of triticale whereas the lowest mean of this trait was achieved from Pishgam genotype of wheat (Table 1). Means comparison analysis for straw yield trait showed that only Sanabad genotype of triticale and Nik genotype of barley had the highest and significant mean for this trait at $5 \%$ probability level and there were significant differences among other investigated genotypes of triticale and Pishgam genotype of bread wheat for this trait at $5 \%$ probability level (Table 1 ). Results of means comparison analysis showed that the highest and lowest means of biological yield were related to Sanabad genotype of triticale and Pishgam genotype of wheat respectively (Table 1). Based on Duncan's multiple range test, the highest and the lowest means of grain yield were corresponded to Pazh genotype of triticale and Pishgam genotype of bread wheat, respectively (Table 1). Means comparison analysis also showed that the highest mean of harvest index was achieved form Jualino genotype of triticale whereas the lowest mean of this trait was achieved form Nik genotype of barley (Table 1). Now, the superiority of triticale for high biomass and yield potential against wheat is well documented (Blum, 2014). Drought stress $\times$ genotype was a significant for $\mathrm{NS} \mathrm{m}^{-2}$, NT and SY (Table 1). Mean comparisons of these traits shows that the highest $\mathrm{NS} \mathrm{m}^{-2}$ belong to ET-89-9 genotypes in cutting irrigation condition. The highest of NT belong to 'Nik' (barley) in cutting irrigation and the highest of SY belong to 'Sanabad' in full irrigation conditions (Table 2).

\subsection{SIMPLE CORRELATION UNDER NORMAL AND DROUGHT STRESS ENVIRONMENTS}

\subsubsection{Normal condition}

Results of simple Pearson's correlation analysis under normal conditions showed that grain yield had positive and significant correlation with plant height, number of seeds per spike, number of seeds per $\mathrm{m}^{2}$, number of spikes per square meter $\mathrm{m}^{2}, 1000$ grain mass, harvest index and spike/stem. Number of days to flowering had negative and significant correlation with plant height,

Table 2: Mean comparisons of Genotypes $\times$ drought stress interaction in different traits

\begin{tabular}{llll}
\hline Genotype $\times$ Drought Stress & NS/m & & SY $\left(\mathrm{g} \mathrm{m} \mathrm{m}^{-2}\right)$ \\
\hline ET-89-9 $\times$ Full Irrigation & $331.0 \mathrm{ab}$ & $\mathrm{NT}$ & $785.6 \mathrm{bc}$ \\
ET-89-11 $\times$ Full Irrigation & $282.3 \mathrm{~b}$ & $5.73 \mathrm{bc}$ & $741.9 \mathrm{bc}$ \\
ET-89-6 $\times$ Full Irrigation & $346.3 \mathrm{ab}$ & $6.20 \mathrm{bcd}$ & $816.3 \mathrm{bc}$ \\
Jualino $\times$ Full Irrigation & $411.7 \mathrm{ab}$ & $5.60 \mathrm{~cd}$ & $785.0 \mathrm{bc}$ \\
Pazh $\times$ Full Irrigation & $264.3 \mathrm{~b}$ & $5.33 \mathrm{~cd}$ & $784.0 \mathrm{bc}$ \\
Sanabad $\times$ Full Irrigation & $253.7 \mathrm{~b}$ & $5.60 \mathrm{~cd}$ & $984.9 \mathrm{ab}$ \\
Nik $($ Barley) $\times$ Full Irrigation & $287.3 \mathrm{~b}$ & $7.07 \mathrm{bc}$ & $1165.6 \mathrm{a}$ \\
Pishgam $($ Wheat $) \times$ Full Irrigation & $240.0 \mathrm{~b}$ & $5.53 \mathrm{~cd}$ & $558.4 \mathrm{c}$ \\
ET-89-9 $\times$ Cutting Irrigation & $416.7 \mathrm{ab}$ & $5.63 \mathrm{~cd}$ & $597.3 \mathrm{c}$ \\
ET-89-11 $\times$ Cutting Irrigation & $257.3 \mathrm{~b}$ & $5.87 \mathrm{~cd}$ & $628.3 \mathrm{c}$ \\
ET-89-6 $\times$ Cutting Irrigation & $282.3 \mathrm{~b}$ & $4.13 \mathrm{~d}$ & $627.0 \mathrm{c}$ \\
Jualino $\times$ Cutting Irrigation & $308.0 \mathrm{~b}$ & $5.67 \mathrm{~cd}$ & $640.7 \mathrm{c}$ \\
Pazh $\times$ Cutting Irrigation & $419.3 \mathrm{ab}$ & $5.20 \mathrm{~cd}$ & $800.0 \mathrm{bc}$ \\
Sanabad $\times$ Cutting Irrigation & $518.3 \mathrm{a}$ & $5.40 \mathrm{~cd}$ & $967.4 \mathrm{ab}$ \\
Nik $($ Barley $\times$ Cutting Irrigation & $222.3 \mathrm{~b}$ & $9.40 \mathrm{a}$ & $838.5 \mathrm{bc}$ \\
Pishgam $($ Wheat $) \times$ Cutting Irrigation & $358.0 \mathrm{ab}$ & $8.27 \mathrm{ab}$ & $673.7 \mathrm{c}$ \\
\hline
\end{tabular}

NT: No. of Tillers, NS $/ \mathrm{m}^{2}:$ No. Spikes $/ \mathrm{m}^{2}$, SY: Straw yield. Means with same letter in each column have not significant difference at $5 \%$ probability level. 
grain yield, biological yield, and straw yield at $1 \%$ probability level and with 1000 seed mass and $5 \%$ probability level (Table 3). These results indicated to it that longer vegetative growth could lead to lower yield in triticale, barley and bread wheat genotypes under drought stress condition. Number of days to maturity had positive and significant correlation with plant height, chlorophyll content, spike length, number of seed per spike, grain yield, harvest index, and spike to shoot ratio traits, whereas this trait had negative and significant correlation with number of tiller at $5 \%$ probability level (Table 3 ). Plant height had negative and significant correlation with number of tiller and positive and significant correlation with stem diameter, spike length, grain yield, biological yield, harvest index, and spike to shoot ratio traits (Table 3 ). Based on simple correlation analysis number of tiller had positive and significant correlation with number of fertile tiller and number of spike per plant at $1 \%$ probability level, whereas this trait had negative and significant correlation with spike length and harvest index characteristics (Table 3). Simple correlation of spike length was positive and significant with number of seed per spike, number of seed $/ \mathrm{m}^{2}$, number of spike $/ \mathrm{m}^{2}$, grain yield, and harvest index traits (Table 3). Based on simple correlation analysis, grain yield of investigated genotypes of triticale, barley and bread wheat had the highest positive and significant correlation with biological yield trait $\left(\mathrm{r}=0.84^{* *}\right)$ under drought stress condition, therefore biological yield along with harvest index, and spike to shoot ratio can be used as selection criteria for grain yield in investigated genotypes of triticale, wheat, and barley genotypes under drought stress condition. The complex nature of drought tolerance need to explore and consider various evaluation criteria of tolerance (Richards 1991; Jones 1993; Grzesiak et al., 2003).

Ramazani et al. (2017) studied the correlation between different agronomic and yield characteristics of eight different genotype of triticale and reported positive and significant correlation of grain yield with date of heading, spike length, and 1000 seed mass traits. In their experiment, the highest positive direct effect on grain yield was related to date of heading whereas the highest negative indirect effect on grain yield belonged to spike length (Ramazani et al., 2017). In another experiment that was conducted under drought stress at reproductive stage of six different genotypes of triticale along with one bread wheat and one durum wheat genotypes, positive and significant correlation of grain yield was reported with seed mass in spike trait (Fayaz \& Arzani, 2011).

\subsubsection{Drought stress condition}

Grain yield had a positive and significant correla- tion with spike to stem ratio, harvest index, straw yield, biological yield, number of spikes per $\mathrm{m}^{2}$, grain number per $\mathrm{m}^{2}$, spike length and plant height under stress conditions. The highest positive correlation was observed between grain yield and biological yield $\left(r=0.88^{\star *}\right)$. Also, grain yield showed negative correlation with number of tillers and number of fertile tillers.

\subsection{DROUGHT TOLERANCE INDICES UNDER DROUGHT STRESS}

The comparison of estimated grain yield under drought stress conditions $\left(\mathrm{Y}_{\mathrm{s}}\right)$, and yield under normal conditions $\left(\mathrm{Y}_{\mathrm{p}}\right)$, for all investigated genotypes revealed that the highest yield was achieved from ET-89-6 genotype of triticale under normal condition, whereas the lowest grain yield was related to Nik genotype of barley under drought stress condition (Table 4). At all $\mathrm{Y}_{\mathrm{p}}$ of all investigated genotypes of triticale and also Nik genotype of barley was less than $\mathrm{Y}_{\mathrm{s}}$, except for Pishgam genotype of wheat that it's $\mathrm{Y}_{\mathrm{s}}$ was higher than $\mathrm{Y}_{\mathrm{p}}$ (Table 4). The highest susceptibility index (SI) was related to ET-89-6 genotype of triticale and this index was negative in Pishgam genotype of bread wheat (-0.012) (Table 4). The estimation of stress susceptibility index (SSI) was negative for ET-89-9 genotype of triticale and also Pishgam genotype of bread wheat, and the highest value of this index was related to Et-89-6 genotype of triticale (Table 4). Genotypes that have SSI less than a unit are drought resistant, because their yield reduction in drought condition is smaller than the mean yield reduction of all genotypes (Fischer \& Maurer, 1978). SSI is a suitable selection index to identify resistant cultivars against susceptible genotypes (Kutlu \& Kinaci, 2010).

This index showed that ET-89-9 is more susceptible to drought stress in the end of growing season than other investigated genotypes of triticale, Nik genotype of barley and Pishgam genotype of wheat. Özkan et al. (1999) used SSI index to distinguish drought tolerance genotypes among 20 investigated genotypes of triticale and reported that selected drought tolerance genotype using this index had not necessarily high grain yield. The highest and lowest values of relative drought index (RDI) were achieved from Pishgam genotype of wheat and ET-89-9 genotype of triticale, respectively (Table 4). According to RDI, genotypes that show the highest value of this index can be select as drought resistant genotypes (Fernandez, 1992).Estimation of tolerance (TOL) index revealed that the highest and the lowest values if this drought tolerance index were related to ET-89-6 and Pishgam genotypes, respectively (Table 4). The larger values of TOL indicate to more sensitivity to stress, thus based on this index, ET- 


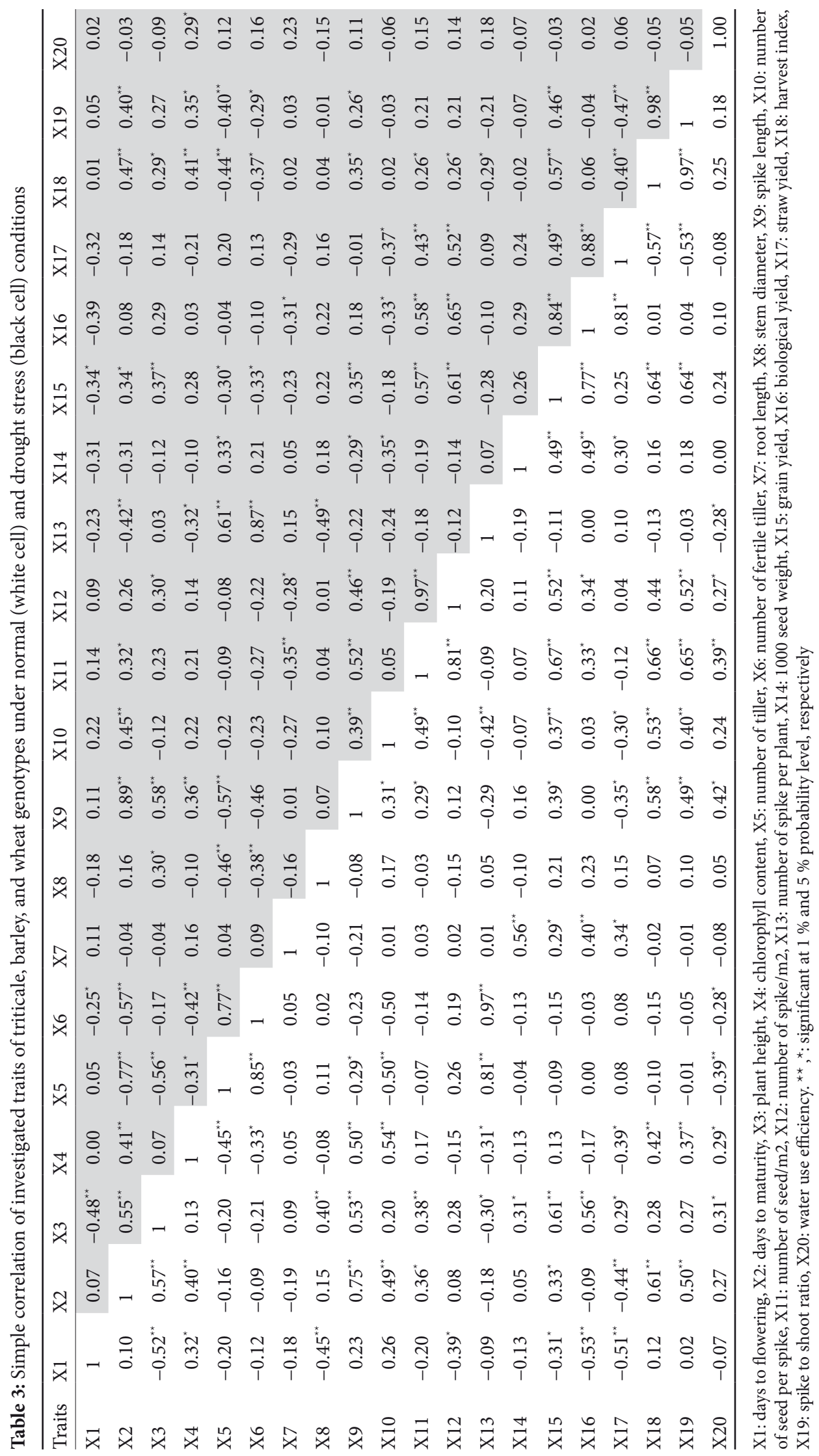



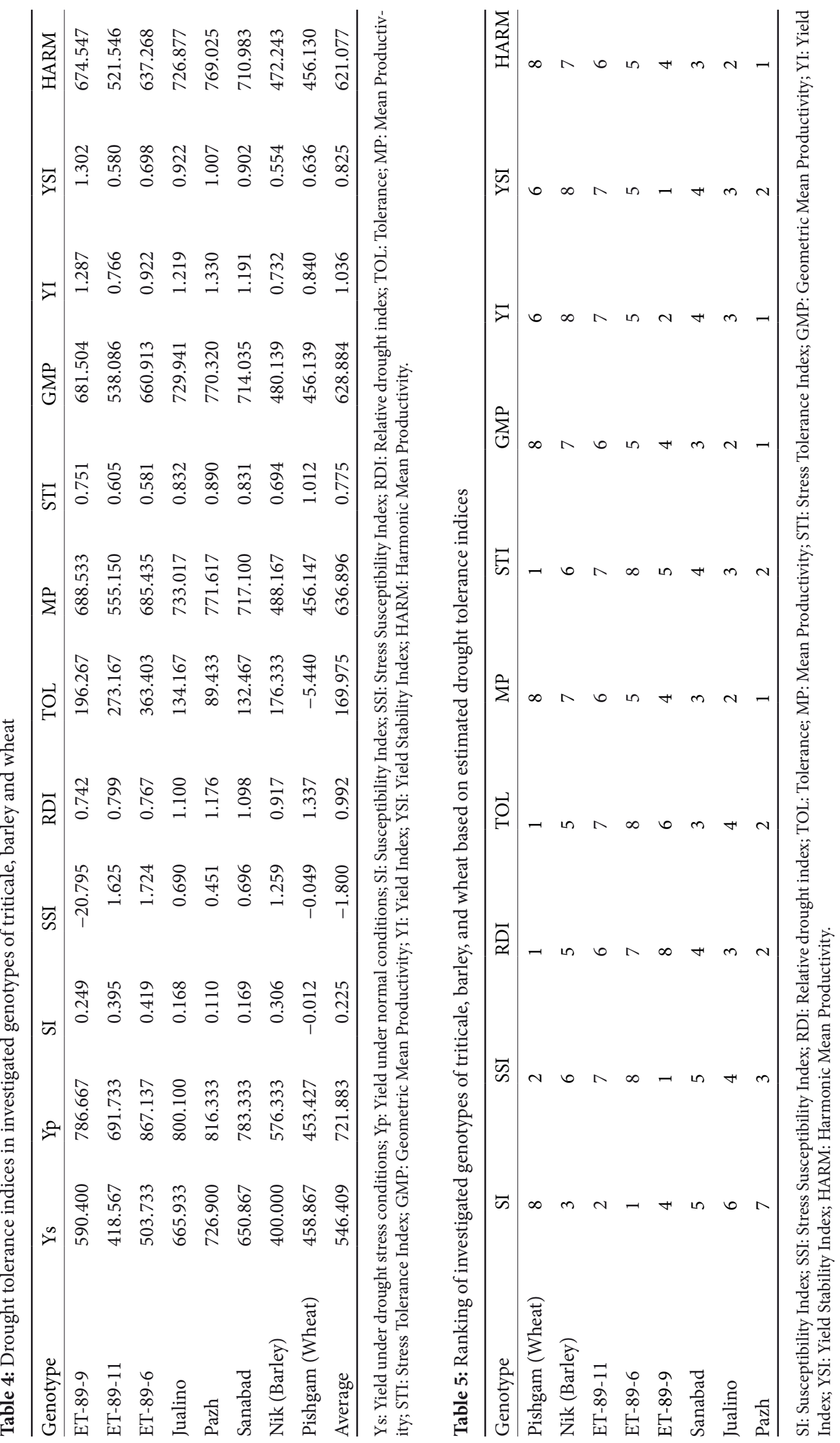
89-6 genotypes was identified as most drought sensitive genotype whereas Pishgham genotype of bread wheat identified as the most tolerant genotypes to drought stress. The highest and lowest values of estimated mean productivity (MP), geometric mean productivity (GMP), and harmonic mean productivity (HARM) were corresponded to Pazh genotype of triticale and Pishgam genotype of bread wheat, respectively (Table 4 ). Since MP is the mean production under both stress and non-stress conditions (Rosielle \& Hamblin,1981), so this index is based on arithmetic means and therefore it has an upward bias due to a relatively larger difference between $\mathrm{Y}_{\mathrm{s}}$ and $\mathrm{Y}_{\mathrm{p}}$, but GMP is less sensitive to large extreme values (Fernandez, 1992). Anyway, based on MP and GMP, Pazh genotype of triticale had more uniform performance in both stress and non-stress conditions than other investigated genotypes in the present study. Calculation of the stress tolerance index (STI) showed that the highest and the lowest values of this index were achieved from Pishgam genotype of bread wheat and ET-89-6 genotype of triticale (Table 4). STI is able to identify cultivars producing high yield under both stress and non-stress conditions (Kutlu \& Kinaci, 2010), therefore this index can help to selection of drought resistance genotypes with acceptable level of grain yield in both irrigated and non-irrigated environments. 'Pazh' and 'Nik' genotypes had the highest and lowest yield index (YI) values, respectively (Table 4). ET-89-9 and 'Nik' genotypes had the highest and lowest values for yield stability index (YSI), respectively (Table 4). As it showed in Eq. 8 (Gavuzzi et al., 1997), YI index refer to rate in stress and mean stress, therefore this index ranks investigated genotypes only based on their

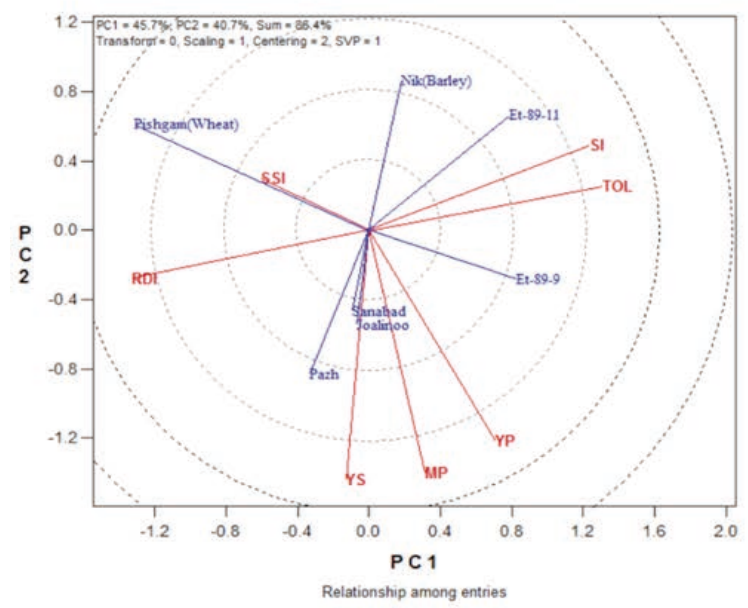

yield under stress, but YSI is the rate of stress and nonstress a genotype, therefore genotypes that show higher YSI are expected to have high yield under both irrigated and irrigated-cut conditions. Pazh genotype of triticale and Pishgam genotype of bread wheat had the highest and lowest values of, respectively (Table 4). The ranking of genotypes based on their calculated drought tolerance indices in presented in Table 5. The highest amounts of MP, GMP, YI, and HARM indexes were related to Pazh genotype of triticale (Table 5). The highest values of SI, SSI, and TOL indexes were related to ET-89-6 genotype of triticale (Table 5). Pishgam genotype of bread wheat had the lowest values of SI, TOL, MP, GMP, and HARM (Table 5). Based on these results, we can conclude that Pazh genotype of triticale can lead to stable production in both stress and non-stress condition, whereas ET-89-6 genotype of triticale can identify as drought susceptible genotype which can lose much of its performance under stress conditions.

\subsection{BIPLOT ANALYSIS}

Grouping of investigated genotypes and estimated drought tolerance indices using biplot analysis can help to better identify superior genotypes for both normal and drought stress environments (Zare, 2012). Results of principal component analysis (PCA) showed that $86.40 \%$ of the total variation was related to first two PCAs (Fig 1). The first PCA with $45.7 \%$ from the total variation of accounted data was correlated with MP, Ys, and Yp (Fig 1), therefore the first dimension refer to av-

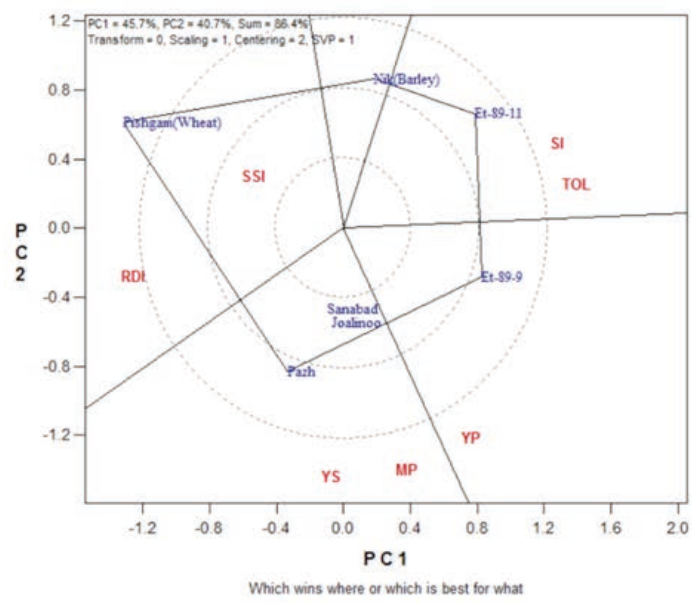

Figure 1: Biplot of drought tolerance indices based on the first two principal components (PC1 and PC2) for genotypes of triticale along with Nik genotype of barley and Pishgam genotype of wheat in non-stress and stress conditions. Ys: Yield under drought stress conditions; Yp: Yield under normal conditions; SI: Susceptibility Index; SSI: Stress Susceptibility Index; RDI: Relative drought index; TOL: Tolerance; MP: Mean Productivity. 

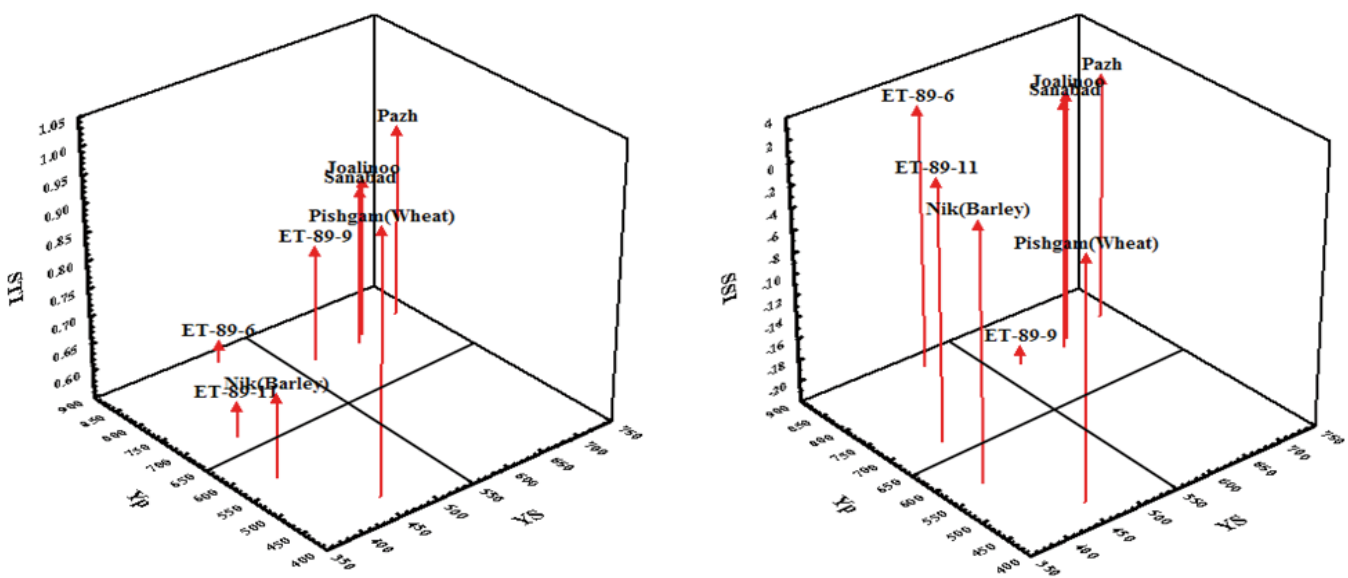

Figure 2: Fernandez's three dimensional biplot for SSI and STI for six investigated genotypes of triticale along with Nik genotype of barley and Pishgam genotype of wheat. Ys: Yield under drought stress conditions; Yp: Yield under normal conditions; SSI: Stress Susceptibility Index; STI: Stress Tolerance Index..

erage potential yield under stress and non-stress conditions. Pazh, Sanabad, Jualino, and ET-89-9 genotypes of triticale were stated in these two sectors, however ET-899 was more near to Yp sector. Therefore, these four genotypes can have high performance under both stress and non-stress conditions. PCA2 with $40.7 \%$ of total variation had positive correlation with SSI and RDI indexes (Fig 1), therefore genotypes that located in this sector are more appropriate for drought stress condition (Pishgam genotype of bread wheat). SI and TOL indexes were located with ET-89-11 and Nik genotypes, therefore, these two genotypes with higher amount of PCA1 and PCA2 are more suitable for durable performance under stress condition.

Based on Fernandez's three dimensional biplot for SSI and STI (Fig. 2), 'Pazh', 'Jualino', 'Sanabad' and 'ET89-9' have high yield under both stress conditions and non-stress conditions, so they have good yield stability. 'Pishgam' (wheat) and 'Nik' (barley) have a good performance only in non-stress conditions, so they have a low yield stability. 'ET-89-6' and 'ET-89-11' genotypes have low yields in both conditions, which, have a low seed yield and low yield stability (Fig. 2).

\section{CONCLUSION}

Significant differences were observed among investigated genotypes of triticale along with Nik genotype of barley and Pishgam genotype of bread wheat. Late drought stress had adverse effect on yield and yield component characteristics of all investigated genotypes. Based on most of the drought tolerance indices, ET-89-
6 genotype of triticale was identified as most drought susceptible genotype, whereas Pishgam genotype and bread wheat and Pazh genotype of triticale was identified as genotype with uniform and durable performance in both irrigated and late drought stress condition. Based on different calculated drought tolerance indices, different ranking of drought resistant and susceptible genotypes were achieved. Anyway, SSI and SI can help to select drought tolerance genotypes in severe drought stress environments, whereas MP, GMP, and STI can help to distinguish drought tolerance genotypes in less severe drought stress environments. Using of MP, GMP, HARM, YI, and YSI can help to selection of genotypes with uniform performance in both stress and non-stress environments. Biplot analysis divides all investigated genotypes into four groups of drought susceptibility based on two first PCAs. Pazh, Sanabad, and Jualino genotypes of triticale had more trend to Ys and MP and showed stable performance under both stress and non-stress conditions. Pishgam genotype of bread wheat was identified as more suitable genotype for severe stress condition.

\section{ACKNOWLEDGMENT}

The authors would like to acknowledge the financial support of University of Birjand for this research under contract number 1395/D/23470.

\section{REFERENCES}

Bassu, S., Asseng, S. \& Richards, R. (2011). Yield benefits of triticale traits for wheat under current and future climates. Field 
Crops Research, 124(1), 14-24. https://doi.org/10.1016/j. fcr.2011.05.020

Blum, A. (2014). The abiotic stress response and adaptation of triticale- A review. Cereal Research Communications, 42(3), 359-375. https://doi.org/10.1556/CRC.42.2014.3.1

Bouslama, M. \& Schapaugh, W.T. (1984). Stress tolerance in soybeans. I. Evaluation of three screening techniques for heat and drought tolerance. Crop science, 24(5), 933-937. https://doi.org/10.2135/cropsci1984.0011183X002400050 026x

Clarke, J.M., Townley-Smith, F., McCaig, T.N. \& Green, D.G. (1984). Growth analysis of spring wheat cultivars of varying drought resistance. Crop Science, 24(3), 537-541. https:// doi.org/10.2135/cropsci1984.0011183X002400030026x

Clarke, J.M., DePauw, R.M. \& Townley-Smith, T.F. (1992). Evaluation of methods for quantification of drought tolerance in wheat. Crop Science, 32(3), 723-728. https://doi. org/10.2135/cropsci1992.0011183X003200030029x

Farooq, M., Wahid, A., Kobayashi, N., Fujita, D. \& Basra, S.M.A. (2009). Plant drought stress: effects, mechanisms and management. Agronomy for sustainable development, 29(1), 185-212. https://doi.org/10.1051/agro:2008021

Farshadfar, E. \& Sutka, J. (2002). Screening drought tolerance criteria in maize. Acta Agronomica Hungarica, 50(4), 411416. https://doi.org/10.1556/AAgr.50.2002.4.3

Fayaz, N., Arzani, A. (2011). Moisture stress tolerance in reproductive growth stages in triticale (X TriticosecaleWittmack) cultivars under field conditions. Crop Breeding Journal, 1(1), 1-12.

Fernandez, G. C. (1992). Effective selection criteria for assessing plant stress tolerance. In Proceedings of the international symposium on adaptation of vegetables and other food crops in temperature and water stress. Taiwan, 13-16 August. pp, 257-270.

Fischer, R. A. \& Maurer, R. (1978). Drought resistance in spring wheat cultivars. I. Grain yield responses. Australian Journal of Agricultural Research, 29(5), 897-912. https://doi. org/10.1071/AR9780897

Fischer, R. A. \& Wood, J. T. (1979). Drought resistance in spring wheat cultivars. III. ${ }^{\star}$ Yield associations with morpho-physiological traits. Australian Journal of Agricultural Research, 30(6), 1001-1020. https://doi.org/10.1071/AR9791001

Gavuzzi, P., Rizza, F., Palumbo, M., Campanile, R. G., Ricciardi, G. L. \& Borghi, B. (1997). Evaluation of field and laboratory predictors of drought and heat tolerance in winter cereals. Canadian Journal of Plant Science, 77(4), 523-531. https:// doi.org/10.4141/P96-130

Grzesiak, S., Grzesiak, M.T., Filek, W. \& Stabryła, J. (2003). Evaluation of physiological screening tests for breeding drought resistant triticale (x Triticosecale Wittmack). Acta Physiologiae Plantarum, 25(1), 29-37. https://doi.org/10.1007/ s11738-003-0033-0

Huang, B. (2000). Role of root morphological and physiological characteristics in drought resistance of plants. Plant- environment interactions. Marcel Dekker Inc., New York, pp, 39-64. https://doi.org/10.1201/9780824746568.ch2

Jones. H. G. (1993). Drought tolerance and water-use efficiency, In: (eds) Smith J. A. C., Griffiths H. Water deficits plant re- sponses from cell to community. Bios Scientific Publishers Limited, Oxford, 193-204.

Kutlu, I. \& Kinaci, G. (2010). Evaluation of drought resistance indicates for yield and its components in three triticale cultivars. Journal of Tekirdag Agricultural Faculty, 7(2), 95-103.

McCaig, T.N. \& Clarke, J.M. (1982). Seasonal changes in nonstructural carbohydrate levels of wheat and oats grown in a semiarid environment. Crop Science, 22(5), 963-970. https://doi.org/10.2135/cropsci1982.0011183X002200050 $016 \mathrm{x}$

Mitra, J. (2001). Genetics and genetic improvement of drought resistance in crop plants. Current science, 80, 758-763.

Oettler, G. (2005). The fortune of a botanical curiosity-Triticale: past, present and future. The Journal of Agricultural Science, 143(5), 329-346. https://doi.org/10.1017/ S0021859605005290

Özkan, H., Genc, I., Yagbasanlar, T. \& Toklu, F. (1999). Stress tolerance in hexaploid spring triticale under Mediterranean environment. Plant breeding, 118(4), 365-367. https://doi. org/10.1046/j.1439-0523.1999.00396.x

Ramazani, S. H. R., Taherpour Kalantari, R., (2019). Evaluating the effect of sowing date and drought stress on morphological and functional characteristics of three genotypes of winter oilseed rape (Brassica napus L.). Acta Agriculturae Slovenica, 113(1), 63-74. https://doi.org/10.14720/ aas.2019.113.1.06

Ramazani, S. H. R., Tajjali, H., Ghaderi, M. G. (2017). Correlation and path coefficient analysis for determining interrelationships among grain yield and related characters in Iranian genotypes of triticale. Bulgarian Journal of Crop Science, 54(1), 35-39.

Ramazani, S. H. R., Tajalli H. \& Ghoudsi, M. (2016). Evaluation of grain yield stability of superior triticale genotypes. Bulgarian Journal of Agricultural Science, 22, 976-981.

Richards, R. A. (1991). Crop improvement for temperate Australia: future opportunities. Field Crops Research, 26(2), 141-169. https://doi.org/10.1016/0378-4290(91)90033-R

Rosielle, A. A. \& Hamblin, J. (1981). Theoretical aspects of selection for yield in stress and non-stress environment. Crop science, 21(6), 943-946. https://doi.org/10.2135/cropsci198 1.0011183X002100060033x

Schneider, K. A., Rosales-Serna, R., Ibarra-Perez, F., CazaresEnriquez, B., Acosta-Gallegos, J.A., Ramirez-Vallejo, P., Wassimi, N. \& Kelly, J. D. (1997). Improving common bean performance under drought stress. Crop Science, 37(1), 4350. https://doi.org/10.2135/cropsci1997.0011183X0037000 $10007 \mathrm{x}$

Wassmann, R., Jagadish, S. V. K., Heuer, S., Ismail, A., Redona, E., Serraj, R., Singh, R. K., Howell, G., Pathak, H. \& Sumfleth, K. (2009). Climate change affecting rice production: the physiological and agronomic basis for possible adaptation strategies. Advances in agronomy, 101, 59-122. https:// doi.org/10.1016/S0065-2113(08)00802-X

Zare, M. (2012). Evaluation of drought tolerance indices for the selection of Iranian barley (Hordeum vulgare L.) cultivars. African Journal of Biotechnology, 11(93), 15975-15981. https://doi.org/10.5897/AJB12.2127 